\title{
Emerging therapies for acute coronary syndromes
}

\author{
Scott M. Lilly ${ }^{1,2}$ and Robert L. Wilensky ${ }^{1,2 *}$ \\ Cardiovascular Division, Hospital of the University of Pennsylvania, Philadelphia, PA, USA \\ ${ }^{2}$ Cardiovascular Institute, University of Pennsylvania, Philadelphia, PA, USA
}

\section{Edited by:}

Issy Laher, University of British

Columbia, Canada

\section{Reviewed by:}

Sanjoy Ghosh, University of British

Columbia, Canada

Subodh Verma, University of Toronto,

Canada

*Correspondence:

Robert L. Wilensky, Cardiovascular Division, Hospital of the University of

Pennsylvania, 3400 Spruce Street,

Gates 9, Philadelphia, PA 19104, USA.

e-mail: robert.wilensky@uphs.

upenn.edu
In the majority of cases acute coronary syndromes (ACS) are caused by activation and aggregation of platelets and subsequent thrombus formation leading to a decrease in coronary artery blood flow. Recent focus on the treatment of ACS has centered on reducing the response of platelets to vascular injury as well as inhibiting fibrin deposition. Novel therapies include more effective P2Y12 receptor blockers thereby reducing inter-individual variability, targeting the platelet thrombin receptor (protease activated receptor 1 ) as well as directly inhibiting factor Xa or thrombin activity. In this review we discuss the clinical data evaluating the effectiveness of these various new ACS treatment options.

\section{Keywords: prasugrel, ticagrelor, bivalirudin, fondaparinux, dabigatran, vorapaxar}

\section{INTRODUCTION}

Over the past two decades improvements in detection and management have reduced the incidence, the morbidity and the mortality of acute coronary syndromes (ACS).Yet there are more than 1 million events yearly in the United States alone and ACS remains a leading cause of death in patients over 65 years of age (Yeh et al., 2010). The term ACS denotes unstable angina, nonST-elevation myocardial infarction and ST-elevation myocardial infarction and ischemic sudden death with the exact diagnosis dependent on the extent and severity of myocardial damage. Necropsy studies have shown that $65 \%$ of sudden deaths resulting from ACS occur from thin-cap fibroatheromas; lesions characterized as possessing a thin fibrous cap $(<65 \mu \mathrm{m})$ overlying a necrotic core. The remaining events are precipitated by superficial erosion of the fibrous cap (Virmani et al., 2000). These processes lead to platelet activation and aggregation, the formation of fibrin rich thrombi, and the partial or total occlusion of the coronary artery resulting in an ACS. With plaque rupture or erosion there is release of tissue factor and exposure of subendothelial collagen and von Willebrand factor (vWF). Circulating platelets adhere to the exposed collagen and vWF and undergo cytoskeletal rearrangement, generation of cyclooxygenase I (COX-I) dependent thromboxane $\mathrm{A}_{2}\left(\mathrm{TXA}_{2}\right)$, and release the contents of stored granules including adenosine diphosphate (ADP). Interaction of $\mathrm{TXA}_{2}$ with the $\mathrm{TXA}_{2}$ receptor and $\mathrm{ADP}$ with its receptor (P2Y12) initiates positive feedback activating additional platelets in a regional manner and promoting the expression

\footnotetext{
Abbreviations: ACS, acute coronary syndrome; AT-III, anti-thrombin-III; CABG, coronary artery bypass grafting; COX-I, cyclooxygenase I; GpIIb-IIIa, glycoprotein IIb-IIIa; MI, myocardial infarction; NNT, number needed to treat; NS, nonsignificant; NSTEMI, non-ST-elevation myocardial infarction; PCI, percutaneous coronary intervention; STEMI, ST-elevation myocardial infarction; TVR, target vessel revascularization; $\mathrm{TXA}_{2}$, thromboxane $\mathrm{A}_{2}$; UA, unstable angina; vWF, von Willebrand factor.
}

of the GpIIb-IIIa receptors. Coincident activation of factor X via tissue factor results in thrombin generation, which elicits additional platelet degranulation and $\mathrm{TXA}_{2}$ release (Chackalamannil and Xia, 2006) and catalyzing the formation of fibrin, which serves as the cross-link between GpIIb-IIIa receptors on neighboring platelets (Figure 1).

Contemporary medical therapies are designed to promote plaque stability, reduce platelet activation and aggregation, prevent thrombus formation, and minimize myocardial oxygen demand. New pharmacotherapies for ACS reflect efforts to improve efficacy and minimize complications of anti-platelet and anti-thrombotic therapies by increasing target specificity and reducing interindividual variation in therapeutic response. In this review we will describe recent advances in pharmacological therapy for ACS with particular attention to platelet aggregation and thrombus formation. Agents targeting glycoprotein IIb/IIIa (Gp IIb/IIIa) receptors will not be discussed.

\section{ASPIRIN AND P2Y12 INHIBITORS}

Aspirin irreversibly blocks COX-I, inhibiting generation of $\mathrm{TXA}_{2}$ and consequent platelet activation. In an early study assessing the effect of aspirin in ACS, 1266 patients with unstable angina were randomized to $324 \mathrm{mg}$ aspirin or placebo. Use of aspirin resulted in a $51 \%$ reduction of either death or MI at 12 weeks $(p=0.0002)$; without an increase in bleeding with sustained benefit at 1 year follow up $(-43 \%, p=0.008$; Lewis et al., 1983). Subsequent smaller studies corroborated this benefit, and a meta-analysis of 15 randomized trials including 135,000 patients identified a reduction in the combined incidence of MI, stroke, or vascular death in ACS patients treated with aspirin $(-30 \pm 4 \%, p<0.0001)$. Subsequently, virtually every trial assessing ACS pharmacotherapy has been performed on the background of aspirin therapy (Lewis et al., 1983; ISIS Collaborative Group, 1988; Antiplatelet Trialists' Collaboration, 1994; Antithrombotic Trialists' Collaboration, 2002). 


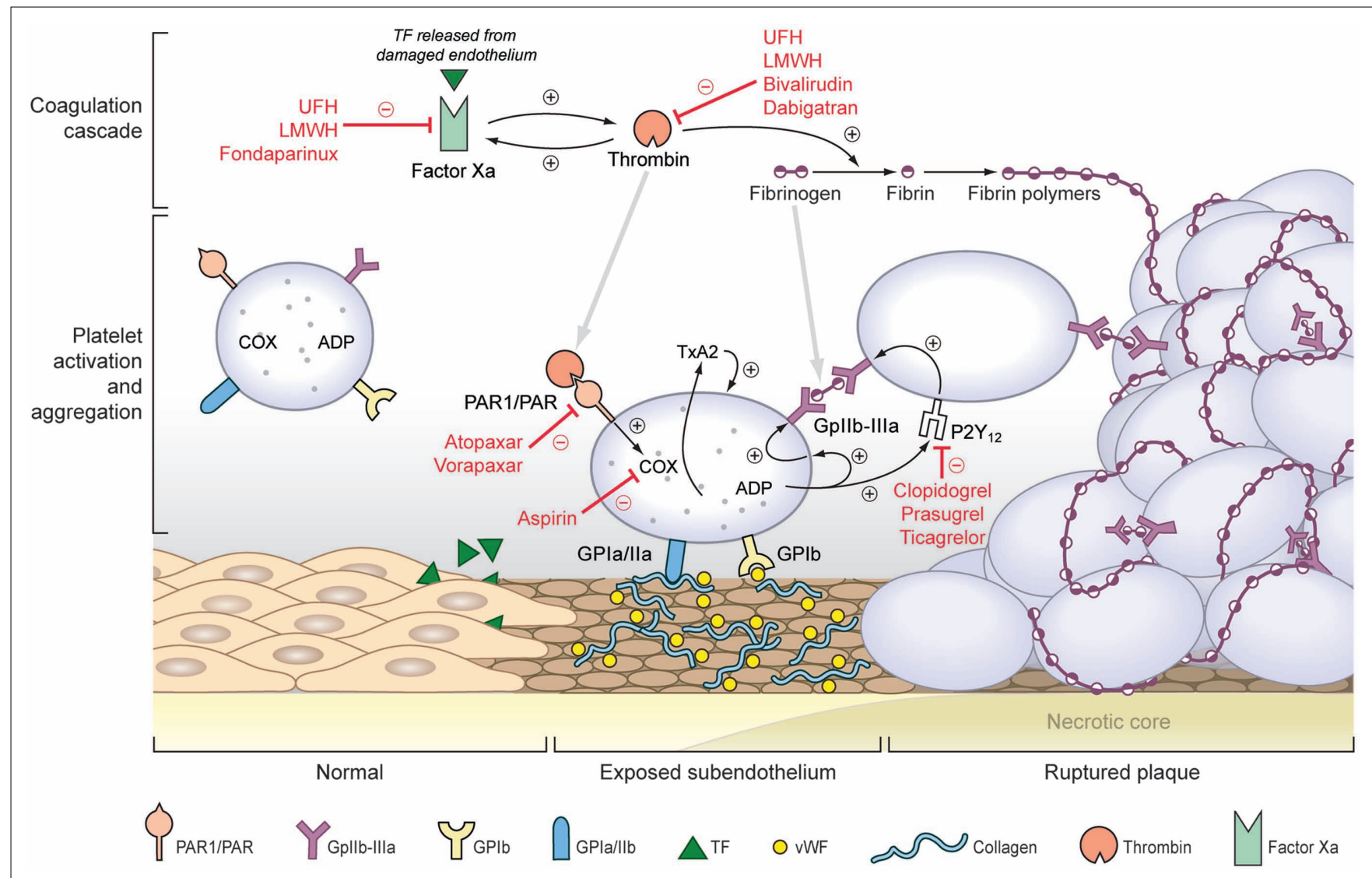

FIGURE 1 | Mechanism of acute coronary syndromes and targets of anti-platelet and anti-thrombotic agents.

The term "aspirin resistance" initially denoted patients who suffered a vascular event while on aspirin therapy, yet specifically refers to the inability of aspirin to sufficiently suppress $\mathrm{TXA}_{2}$ production or platelet aggregation in vitro (Hennekens et al., 2004). The determination of aspirin resistance is complicated by the variable prevalence (6-26\%) among studies depending on the laboratory assay employed (Gum et al., 2001; Gasparyan et al., 2008). Small prospective observational studies have identified increases in the risk of MI (OR 2.0, CI 1.2-3.4, $p=0.006$ ), cardiovascular death (OR 3.5, CI 1.7-7.4, $p<0.001$ ), and composite death, MI or CVA (OR 3.12, CI 1.1-8.9, $p=0.03$ ) in patients with high platelet reactivity (HPR) on aspirin therapy (Eikelboom et al., 2002; Gum et al., 2003; Gasparyan et al., 2008). As a result, the concept of dual anti-platelet therapy (DAPT) emerged in order to reduce the rate of vascular events among those with HPR on aspirin therapy, and specifically to reduce the rate of reinfarction during and after percutaneous coronary intervention (PCI).

Clopidogrel is a thienopyridine pro-drug (Table 1; Figure 2) that requires cytochrome 2C19 (CYP2C19) biotransformation to the active metabolite, an irreversible P2Y12 receptor inhibitor. In a large prospective secondary prevention trial $(n=19,185)$, clopidogrel alone compared to aspirin did not significantly reduce recurrent vascular events (stroke, MI, or vascular death) among those with a history of myocardial infarction $(-3.7 \%, p=0.66)$, and was associated with similar rates of bleeding ( 9.27 vs. 9.28\%;
CAPRIE Steering Committee, 1996). However, when administered together, clopidogrel and aspirin provide more complete and uniform suppression of platelet activation via dual pathways for the lifespan of the platelet (average of 5-7 days; Moshfegh et al., 2000). The CURE trial randomized 12,562 patients with UA or NSTEMI to aspirin or DAPT with aspirin and clopidogrel. Patients randomized to DAPT had a reduced incidence of composite cardiovascular death, non-fatal MI, or stroke which was evident at $24 \mathrm{~h}$ (HR 0.66 , CI $0.51-0.86, p<0.05$ ) and persisted for at least 12 months (HR 0.80 , CI $0.72-0.90, p<0.001)$. The event rate was driven primarily by a reduction in non-fatal MI. Not unexpectedly, the combination of clopidogrel and aspirin was associated with increased major bleeding rates (HR 1.38, CI 1.12-1.67, $p=0.001$ ), although there was no difference in life threatening bleeding. Among the subgroup managed with a planned invasive strategy, the addition of clopidogrel was also associated with a significant reduction in composite cardiovascular death, non-fatal MI, or urgent target vessel revascularization at 30 days (HR 0.70 , CI $0.50-0.97$, $p=0.03$ ), with no difference in major bleeding (HR 1.13, CI 0.612.1, $p=0.69$; Mehta et al., 2001; Yusuf et al., 2001; Wright et al., 2011).

Despite these population level benefits, there is considerable inter-individual variability in response to clopidogrel that at least partially result from heterogeneity in CYP2C19 (Angiolillo et al., 2007). The most common CYP2C19 variant is CYP2C19(2, 
Table 1 | Pharmacodynamics and pharmacokinetics of P2Y12 inhibitors in ACS.

\begin{tabular}{|c|c|c|c|c|c|}
\hline Drug & Drug class & Half-life & Metabolism & Elimination & Onset* \\
\hline Clopidogrel & Thienopyridine & $\begin{array}{l}6 \mathrm{~h} \text { (pro-drug), } 30 \mathrm{~min} \\
\text { (active metabolite) }\end{array}$ & Primarily CYP2C19 & Renal and gastrointestinal & $2 \mathrm{~h}$ \\
\hline Ticagrelor & Cyclo-pentyl-triazolo-pyrimidine & $8-9 h$ & Primarily CYP3A4 & Hepatic and gastrointestinal & $2-3 h$ \\
\hline
\end{tabular}

${ }^{*}$ Refers to loading dose administration.<smiles>COC(=O)[C@H](c1ccccc1Cl)N1CCc2sccc2C1</smiles>

Clopidogrel<smiles>CC(=O)Oc1cc2c(s1)CCN(C(C(=O)C1CC1)c1c(F)cccc1Cl)C2</smiles>

Prasugrel

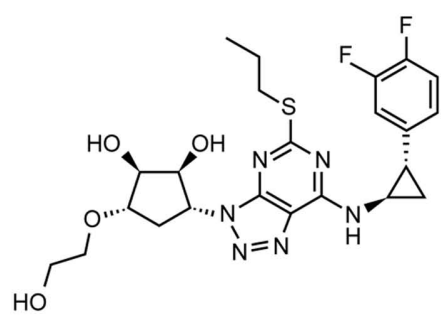

Ticagrelor

FIGURE 2 | Structure of P2Y12 inhibitors.

which has an allelic frequency between 25 and 55\% depending on the ethnic population. Individuals with at least one copy of CYP2C19(2 have reduced plasma concentrations of the active clopidogrel metabolite and have reduced in vitro platelet responsiveness to clopidogrel (Kim et al., 2008; Kubica et al., 2011). Moreover, the CYP2C19(2 variant has been associated with significant increases in the risk of vascular events in a number of prospective studies and sub-studies of large ACS trials (reviewed elsewhere; Angiolillo et al., 2007; Kubica et al., 2011).

The concept of "tailored" anti-platelet therapy has emerged to describe an approach of providing stronger platelet inhibition to those patients with a lower risk of bleeding, in the early phases of ACS when ischemic complications are the highest, or in patients with residual HRP on DAPT (Wiviott et al., 2007; Antman et al., 2008). The latter have been identified as a high risk subset, with as much as a 6.7 -fold increase in the 30-day risk of composite death, myocardial infarction, or revascularization in those undergoing PCI (Hochholzer et al., 2006). In patients with HPR, clopidogrel dose escalation can incrementally reduce platelet activity and decrease the incidence of HPR from 37 to $14 \%$ ( $p=0.002$; Gladding et al., 2008). However, whether HPR should dictate subsequent therapy is unclear. The GRAVITAS trial randomized patients that had undergone PCI with subsequent identification of HPR to placebo or an additional loading dose of clopidogrel $(600 \mathrm{mg})$ and increased maintenance therapy $(150 \mathrm{mg}$ daily). There was no difference in the composite MI, cardiovascular death, or stent thrombosis rate at 6 months (HR 1.01, CI 0.58-1.76), despite a dose-associated reduction in HPR in those randomized to higher-dose clopidogrel ( 38 vs. $60 \%, p<0.001$; Price et al., 2011).

In order to overcome the impact of CYP2C19 heterogeneity on platelet responsiveness novel ADP receptor antagonists have been developed. Prasugrel is a thienopyridine structurally similar to clopidogrel (Table 1; Figure 2) but less dependent on CYP2C19 biotransformation, and provides faster and more pronounced platelet inhibition (Table 1; Mega et al., 2009b). In TRITON-TIMI 38 , patients $(n=13,608)$ with ACS and planned PCI were randomized to prasugrel (60 mg loading dose followed by $10 \mathrm{mg}$ daily) or clopidogrel (300 mg loading dose followed by $75 \mathrm{mg}$ daily) for a median of 14.5 months. Prasugrel significantly reduced the incidence of non-fatal MI, (HR 0.76, CI 0.67-0.85, $p<0.001$ ) driving a significant reduction in the composite cardiovascular outcome that also included cardiovascular death and stroke (HR 0.81, CI $0.73-0.90, p<0.001)$. This benefit was associated with a significant increase in the risk of bleeding, including that classified as life threatening (HR 1.5, CI 1.1-2.1, $p=0.01$ ) and fatal (HR 4.2, CI 1.6-11.1, $p=0.002$; Wiviott et al., 2007).

TRIGGER-PCI, designed to evaluate the efficacy of prasugrel in patients undergoing PCI with HPR on clopidogrel therapy, was stopped after a preliminary analysis revealed low event rates and an unlikely benefit of prasugrel. The ongoing TRILOGY-ACS trial is evaluating prasugrel in patients with ACS undergoing medical management with HPR on clopidogrel therapy (Chin et al., 2010).

Unlike the thienopyridines, ticagrelor does not require conversion to its active metabolite and provides reversible inhibition of P2Y12 - features that theoretically confer less inter-individual variation (Table 1; Figure 2). In preclinical studies ticagrelor was not associated with greater bleeding than clopidogrel and provided more rapid and effective platelet inhibition (Husted et al., 2006; Storey et al., 2007). The PLATO trial compared ticagrelor to clopidogrel in ACS. In PLATO 18,624 patients admitted with ACS were randomized to ticagrelor ( $180 \mathrm{mg}$ load, $90 \mathrm{mg}$ twice daily) or clopidogrel (300 or $600 \mathrm{mg}$ load, $75 \mathrm{mg}$ daily). Ticagrelor was associated with a significant reduction in the composite endpoint 
of vascular death, myocardial infarction, or stroke (RR $0.84, \mathrm{CI}$ $0.77-0.92, p=0.0003$ ) as well as all cause mortality (HR 0.78, CI $0.69-0.89, p<0.001)$ with no significant increase in the rate of composite major bleeding (HR 1.04, CI 0.95-1.13, $p=0.43$ ). There was an increase in the intracranial bleeding rate (HR 1.87, CI $0.98-$ $3.58, p=0.06$; Wallentin et al., 2009) although subgroup analyses demonstrated no increased bleeding rates in those identified as "high risk" from TRITON-TIMI 38 including those $>75$ years old (HR 1.04, CI 0.84-1.29, $p=1.0$ ), <60 kg (HR 0.82, CI 0.60-1.12, $p=0.12$ ) and with known cerebrovascular disease (HR 0.99, CI 0.71-1.37, $p=0.77$; Wallentin et al., 2009).

Two novel anti-platelet agents have recently entered clinical trials for ACS: atopaxar and vorapaxar. Both are synthetic antagonists of the platelet thrombin receptor (protease activated receptor 1), and have the potential advantage of impeding platelet aggregation during rapid thrombin formation such as ACS (Morrow et al., 2009). In phase II trials with atopaxar, Japanese patients with ACS $(n=241)$ were randomized to $50-200 \mathrm{mg}$ daily or placebo in addition to standard therapy ( $>96 \%$ aspirin, $>89 \%$ clopidogrel) for 12 weeks. The bleeding rate was similar among all doses of atopaxar and placebo (5.0 vs. $6.6 \%$, NS). However, there was an increased frequency of liver enzyme elevation among patients randomized to the $100(6.2 \%)$ and $200 \mathrm{mg}(14.8 \%)$ doses (Goto et al., 2010b). In phase II trial of vorapaxar, patients $(n=1030)$ with stable CAD undergoing non-urgent PCI receiving vorapaxar (10-40 mg load, with $0.5-2.5 \mathrm{mg}$ daily) for 60 days had bleeding rates that were comparable to placebo (41\% grouped vorapaxar vs. $35 \%$ placebo, NS). Moreover, those randomized to vorapaxar had non-significant reductions composite death or myocardial infarction ( $5 \%$ grouped vorapaxar vs. $7 \%$ placebo, NS; Becker et al., 2009). Phase III trials including more than 40,000 patients with ACS (TRACER) or a history of vascular disease (TrA2PTIMI 50) are underway (Morrow et al., 2009; Van De Werf, 2010).

\section{ANTI-THROMBOTIC AGENTS HEPARINS}

The heparins complex with anti-thrombin-III (AT-III) and accelerate AT-III mediated inhibition of factor $\mathrm{Xa}$ and thrombin (Figure 1). Unfractionated heparin (UFH) represents the cornerstone of anti-thrombotic therapy in ACS, but has a number of limitations. UFH poorly inhibits clot-associated thrombin activity resulting in persistent proaggregant and procoagulant thombin activity at the site of arterial thrombosis. Additional concerns with UFH include heparin-induced thrombocytopenia and thrombosis (HITT), the necessity of frequent monitoring, and platelet-activating effects at therapeutic doses (Xiao and Theroux, 1998).

Low molecular weight heparin (LMWH) provides greater factor Xa inhibition, a reduced incidence of HITT, and more predictable bioavailability and elimination characteristics than UFH. A number of trials comparing enoxaparin to UFH demonstrated comparable or superior efficacy with regard to ischemic ACS endpoints yet small increases in bleeding with enoxaparin, particularly when invasive strategies were employed (Antman et al., 1999, 2006; Goodman et al., 2000; Wallentin et al., 2003; Ferguson et al., 2004). A meta-analysis encompassing 12 randomized trials ( $n=49,088)$ comparing enoxaparin to UFH in ACS concluded that there were significant reductions in the incidence of MI (HR 0.75 , CI $0.65-0.86, p<0.001)$ at 30 days, with an increase in major bleeding (HR 1.25, CI 1.04-1.50, $p=0.02$ ). The net clinical benefit endpoint (death, MI, or major bleeding), approached significance at 30 days (HR 0.90, CI 0.76-1.00, $p=0.051$; Murphy et al., 2007). Other LMWHs have also been evaluated in ACS but are in less frequent clinical use due to inferior clinical results (tinzaparin, dalteparin) or increased bleeding (nadroparin; Klein et al., 1997; Michalis et al., 2003; Katsouras et al., 2005; Table 2). As LMWHs are cleared renally and given that monitoring tests are less reliably available, UFH is preferable in those with advanced chronic kidney disease.

\section{DIRECT FACTOR XA INHIBITORS}

Direct factor Xa inhibitors block the coagulation cascade at an earlier step and are able to inhibit free and clot-associated factor Xa. Currently there is one direct factor Xa inhibitor FDA approved for use in ACS (fondaparinux) with three others in preclinical trials (apixaban, rivaroxaban, otamixaban). Fondaparinux is a synthetic pentasaccharide that mimics the AT-III binding portion of heparin and enhancing the anti-factor Xa activity $>300$-fold (Table 3; Figure 3). It is administered parenterally, eliminated

\section{Table 2 | Low molecular weight heparins in ACS.}

ESSENCE In 3171 patients with UA or NSTEMI, enoxaparin reduced composite death, $\mathrm{MI}$, recurrent angina at 30 days $(19.8 \mathrm{vs.} 23.3 \%, p=0.016)$ and 12 months (32.0 vs. $35.7 \%, p=0.022$ ) with no change in major bleeding (6.5 vs. $7.0 \%$; Goodman et al., 2000)

TIMI 11B In 3910 patients with UA or non-Q wave MI, enoxaparin reduced composite death, MI, or urgent revascularization at 8 days (OR 0.83 , Cl $0.69-1.0, p=0.048$ ) with no increase in major bleeding (Antman et al., 1999)

SYNERGY In 10027 patients with NSTEMI and planned early invasive strategy, enoxaparin did not reduce composite death or non-fatal MI at 1 (14.0 vs. $14.5 \%, \mathrm{NS}$ ) or 6 months (17.6 vs. $17.8 \%, \mathrm{NS})$; increased major bleeding $(9.1$ vs. $7.6 \%$; Ferguson et al., 2004)

FRISC In 1506 patients with NSTEMI randomized to placebo or dalteparin. Dalteparin reduced composite death and $\mathrm{MI}$ at 6 days (HR 0.37 , Cl $0.20-0.68, p=0.001$ ), with no change in major or minor bleeding (FRISC Study Group, 1996)

FRIC In 1482 patients with ACS dalteparin compared to UFH did not reduce composite death, MI, angina recurrence at 6 days $(\mathrm{HR} 1.18$, Cl $0.84-1.66, p=0.33$ ), there was no difference in major bleeding (1.0 vs. $1.1 \%$; Klein et al., 1997)

FRAXIS In 3468 patients with ACS nadroparin compared to UFH resulted in similar rates of composite cardiac death, MI, refractory angina, or recurrence of angina at day 14 (18.1 vs. 20.1\%, NS) with increased major bleeding (3.5 vs. 1.6\%, p<0.001; FRAX. I. S. Study Group, 1999)

EVET In 438 patients with ACS, enoxaparin compared to tinzaparin reduced composite recurrent angina, MI, or death at 30 days (17.7 vs. $28.0 \%$, $p=0.012$ ) with no difference in major bleeding ( $<2$ patients per group, NS; Michalis et al., 2003) 
Table 3 | Pharmacodynamics and pharmacokinetics of anti-coagulants in ACS.

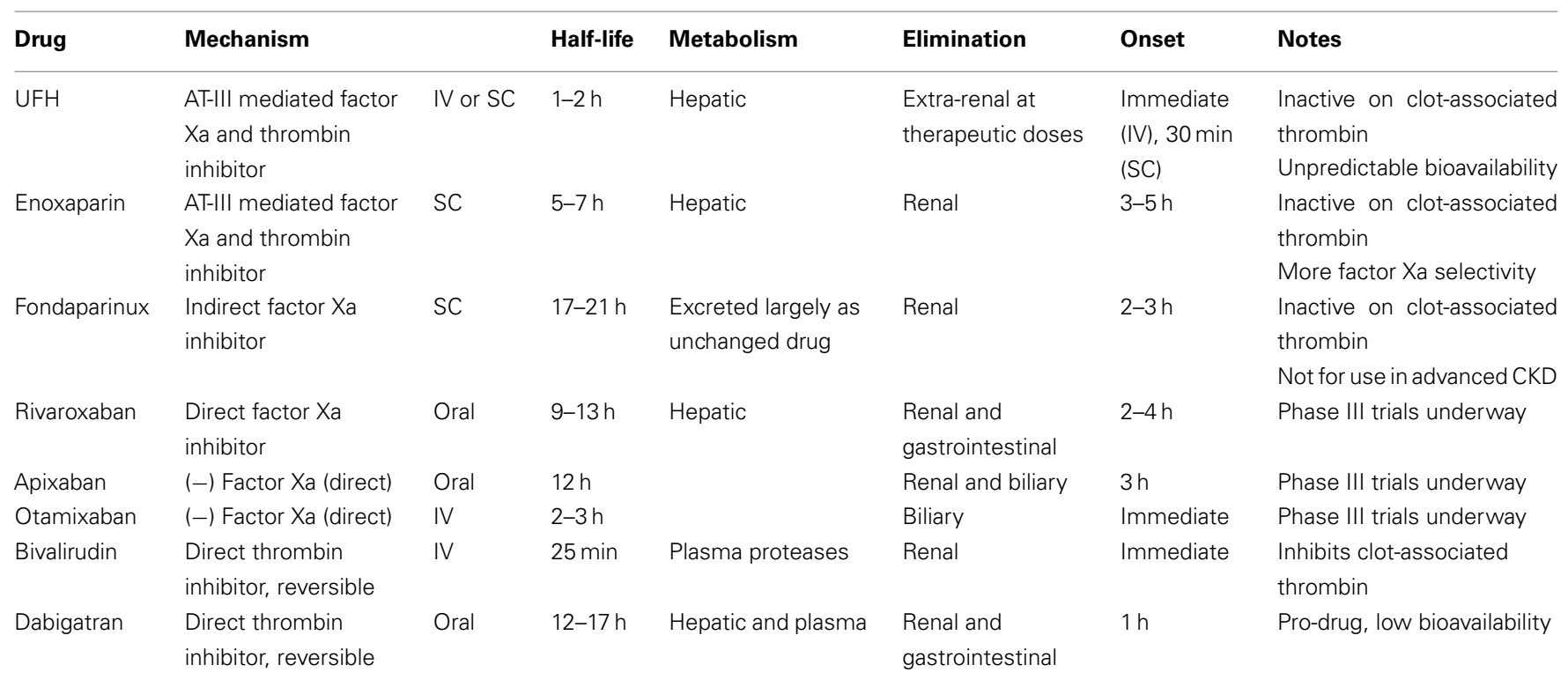
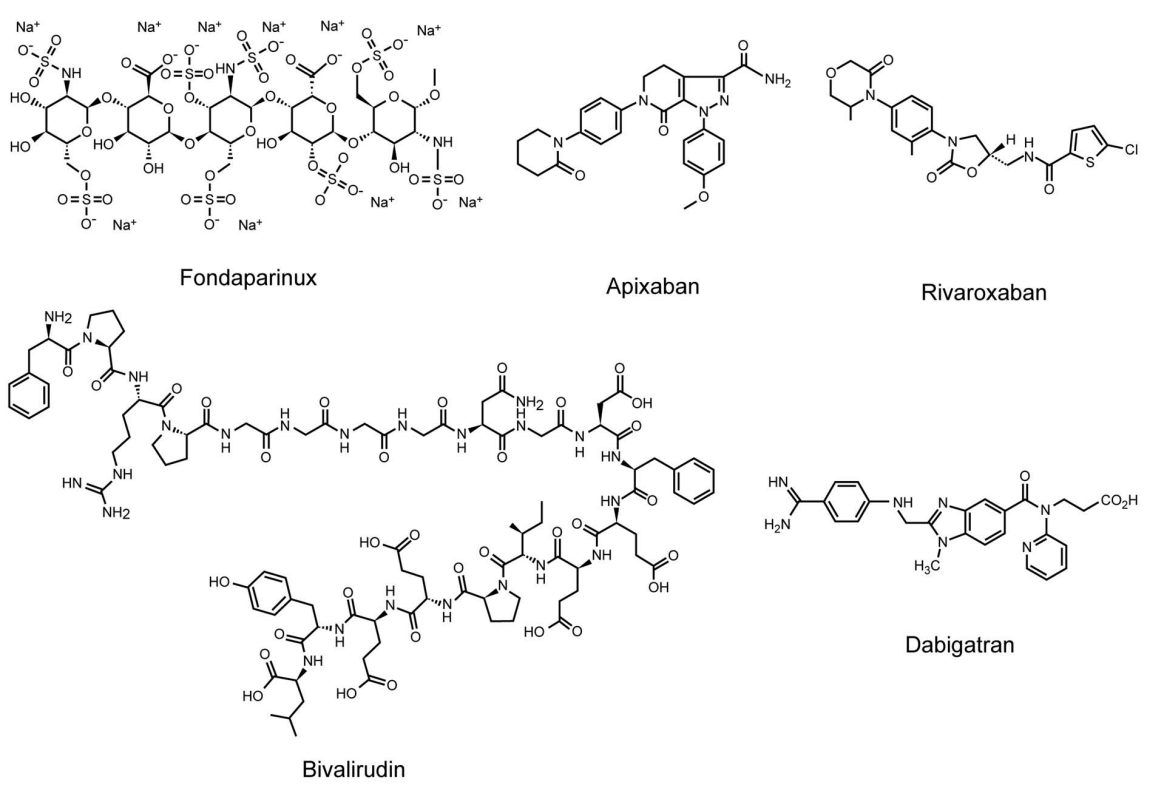

Dabigatran

FIGURE 3 | Structure of factor Xa and direct thrombin inhibitors.

renally, with little inter-individual variability and no need for routine monitoring.

The utility of fondaparinux in ACS was first assessed in the dose finding PENTALYSE trial. STEMI patients $(n=333)$ undergoing thrombolysis were randomized to $48-72 \mathrm{~h}$ of UFH or one of five fondaparinux doses for 5-7 days. Patients receiving fondaparinux had lower 30 day revascularization rates ( 39 vs. $51 \%, p=0.054$ ) with a similar major bleeding risk (7.1 vs. 7.1\%; Coussement et al., 2001). In the PENTUA trial patients with UA or NSTEMI were randomized to one of four doses of fondaparinux or enoxaparin for a period for 3-7 days after identification of ACS. Fondaparinux at the lowest dose ( $2.5 \mathrm{mg}$ daily) provided a non-significant reduction in composite death, MI, or recurrent ischemia at 9 days (27.9 vs. $35.7 \%$ in the enoxaparin group, NS) with no major bleeding and comparable rates of minor bleeding ( 3.9 vs. $4.8 \%$, NS; Simoons et al., 2004).

In the largest ACS trial to date (OASIS-5), over 20,000 patients with UA or NSTEMI were randomized to fondaparinux $(2.5 \mathrm{mg}$ daily) or enoxaparin ( $1 \mathrm{mg} / \mathrm{kg}$ twice daily) for a mean of 6 days. There was no difference in the incidence of composite death, nonfatal MI, or refractory ischemia (HR 1.01, CI 0.9-1.13) between fondaparinux and enoxaparin. However, major bleeding was 
significantly decreased with fondaparinux at 9 days (HR 0.52, CI $0.44-0.61, p<0.001)$ and all cause mortality was lower at 30 (HR 0.83 , CI $0.71-0.91, p=0.02$ ) and 180 days (HR 0.89, CI 0.80-1.0, $p=0.05$; Yusuf et al., 2006a). OASIS- 6 was designed to determine whether fondaparinux was superior to UFH in STEMI patients who underwent mechanical revascularization or pharmacological thrombolysis (Yusuf et al., 2006b). Patients were randomized to fondaparinux (2.5 mg daily for 8 days or until discharge) or UFH (for 24-48 h); those in which UFH was deemed unnecessary (primarily following streptokinase administration) were randomized to fondaparinux or placebo. Fondaparinux was associated with a significant reduction in the incidence of the death or reinfarction at 30 days (HR 0.86, CI $0.77-0.96, p=0.008$ ); an effect that persisted to 6 months. There was no difference in bleeding rates.

The reductions in the composite cardiovascular outcomes with fondaparinux in the OASIS trials were restricted to those who underwent conservative management or thrombolysis, while the benefit of fondaparinux was not apparent in patients who underwent primary PCI. Furthermore, fondaparinux was associated with increased catheter related thrombi, prompting the subsequent use of procedural intravenous fondaparinux. In the event patients managed under a conservative strategy proceed to PCI on fondaparinux, current guidelines recommend a transition to an agent with anti-thrombin activity.

Otamixaban is a synthetic parenteral factor Xa inhibitor with a rapid onset of action and biliary clearance (Table 3; Figure 3). Phase II trials in patients undergoing planned PCI and those with high risk ACS are promising. Compared to UFH with eptifibatide, otamixaban has been associated with reductions in the rate of death or myocardial infarction at 7 days (HR 0.52, CI 0.28-0.98 with $0.105 \mathrm{mg} / \mathrm{kg} / \mathrm{h}$ ) with comparable rates of bleeding (3.1 vs. 2.7\%; Cohen et al., 2007; Sabatine et al., 2009). The ongoing TAO trial is powered for ischemic endpoints and is evaluating otamixaban vs. UFH and eptifibatide in patients with ACS undergoing a planned invasive strategy.

Two orally administered synthetic factor Xa inhibitors are presently in phase III trials: rivaroxaban and apixaban (Table 3; Figure 3; Rothberg et al., 2005). Rivaroxaban is an orally administered factor Xa inhibitor, with high bioavailability and a rapid onset of action. ATLAS TIMI 46 was a phase II trial in which patients admitted with ACS and subsequently stabilized were randomized to placebo or escalating doses of rivaroxaban. Compared to placebo, rivaroxaban was associated with a non-significant decrease in the primary efficacy endpoint (death, MI, stroke, recurrent ischemia requiring revascularization) at the lowest dose (5 mg twice daily; HR 0.60, CI 0.29-1.25) with dose-dependent increases in bleeding (HR 1.71, CI 0.76-3.85 with $5 \mathrm{mg}$ twice daily; Mega et al., 2009a). A phase III trial of 2.5 and $5 \mathrm{mg}$ twice daily rivaroxaban is presently underway (ATLAS 2 TIMI 51).

Phase II trials with apixaban have yielded similar results (Alexander et al., 2009). The phase III APRAISE-2 trial, patients with ACS $(n=7832)$ were randomized to placebo or $5 \mathrm{mg}$ twice daily of apixaban in addition to standard DAPT. At a mean follow up of 241 days, apixaban therapy was not associated with a reduction in composite cardiovascular death, MI, or stroke (HR 0.97, CI $0.8-1.1, p=0.51)$ while resulting in increased major bleeding (HR 2.59, CI 1.5-4.5, $p=0.001$; Alexander et al., 2011).

\section{DIRECT THROMBIN INHIBITORS}

Unlike the heparins, direct thrombin inhibitors are independent of AT-III, reduce the formation of fibrin monomers and abrogate the direct platelet-activating effects of thrombin on platelets. Direct thrombin inhibitors are also active on clot-bound thrombin, providing a regional specificity that heparins lack. Bivalirudin is approved for ACS, while dabigatran is currently in clinical trials.

Bivalirudin is a synthetic and reversible direct thrombin inhibitor (Table 3; Figure 3; Sibbing et al., 2008). Initially evaluated in patients with unstable or post-infarction angina undergoing planned angioplasty $(n=4098)$, bivalirudin therapy $(1 \mathrm{mg} / \mathrm{kg}$ bolus then $2.5 \mathrm{mg} / \mathrm{kg} / \mathrm{h}$ ) reduced composite death, myocardial infarction, and repeat revascularization at 7 days (HR $0.78, \mathrm{CI}$ $0.62-0.99, p=0.039$ ) with a reduced risk of bleeding (HR 0.34, CI $0.26-0.45, p<0.001$; Bittl et al., 2001). Subsequently REPLACE-2 was designed to compare the combination of UFH and GpIIbIIIa inhibition to bivalirudin $(0.75 \mathrm{mg} / \mathrm{kg}$ bolus, followed by $1.75 \mathrm{mg} / \mathrm{kg} / \mathrm{h}$ for procedure duration) with provisional GpIIb-IIIa inhibition (if procedural complications dictated) in the setting of urgent or elective PCI $(n=6010)$. Bivalirudin was associated with a similar incidence in composite rate of death, myocardial infarction, and urgent revascularization ( 7.6 vs. $7.1 \%, p=0.40)$, with a highly significant decrease in bleeding ( 2.4 vs. $4.1 \%, p<0.001$; Lincoff et al., 2003).

These trials, together with CACHET (Bittl et al., 2001; Lincoff et al., 2002) supported the use of bivalirudin during PCI, although patients with high risk ACS had been excluded. The ACUITY trial randomized nearly 14,000 patients with high risk UA or NSTEMI to (1) UFH or LMWH plus GpIIb-IIIa inhibitor, (2) bivalirudin plus GpIIb-IIIa inhibitor, or (3) bivalirudin alone. Bivalirudin alone conferred similar efficacy with respect to the primary cardiovascular endpoint (death, MI, urgent revascularization; HR 1.08 , CI $0.93-1.24, p<0.001$ for non-inferiority) with significantly reduced major bleeding (HR 0.53, CI 0.43-0.65, $p<0.001$ ) compared to the heparin group (Stone et al., 2006).

Finally, the HORIZONS-AMI trial was designed to specifically address whether or not bivalirudin offered a superior risk-benefit profile in patients with STEMI undergoing planned PCI. Patients with STEMI $(n=3602)$ within the preceding $12 \mathrm{~h}$ were randomized to heparin and GpIIb-IIIa or bivalirudin monotherapy $(0.75 \mathrm{mg} / \mathrm{kg}$ bolus, then $1.75 \mathrm{mg} / \mathrm{kg} / \mathrm{h})$, with antithrombin therapies generally discontinued at PCI completion. Bivalirudin was associated with a reduced incidence of the composite outcome (death, reinfarction, revascularization, stroke, or major bleeding) at 30 days, driven primarily by decreased rates of major bleeding (HR 0.60, CI 0.46-0.77, $p<0.001$ ), and death. All cause mortality at 30 days was significantly lower in the bivalirudin group (HR 0.66, CI 0.44-1.0, $p=0.047$ ), an effect maintained at 3 year follow up. The bleeding and survival benefits of bivalirudin were evident in those that had received heparin therapy prior to randomization, and at all stages of renal disease - subgroups in where LMWH have proven less safe (Ferguson et al., 2004; Cohen et al., 2006), or are unadvised due to primary renal elimination and concern for bleeding risk (Robson, 2000; Sun et al., 2007). Whether or not early initiation of bivalirudin provides incremental benefit is the focus of the ongoing EUROMAX trial, in which patients with STEMI and 


\section{Table 4 | Recent trials of ACS therapies.}

\section{CLOPIDOGREL}

\section{GRAVITAS}

Patients that underwent DES implantation with HPR on clopidogrel therapy were randomized to standard (75 mg daily) or high dose clopidogrel (150 mg daily). Primary endpoint was CV death, NFMI, definite, or probable stent thrombosis

High dose clopidogrel did not reduce composite primary outcome (Price et al., 2011)

\section{PRASUGREL}

TRITON-TIMI 38 sub-studies

Prasugrel conferred a reduction in primary endpoint in patients not undergoing stent implantation ( $\mathrm{HR} 0.82, \mathrm{Cl} 0.53-1.25, \mathrm{p}=0.27$ ), with an increase in non-CABG related major bleeding (0 vs. 5 events; Pride et al., 2009)

Prasugrel reduced incidence of primary endpoint in patients in patients that did ( $\mathrm{HR} \mathrm{0.76,} \mathrm{Cl} \mathrm{0.64-0.90)} \mathrm{and} \mathrm{did} \mathrm{not} \mathrm{(} \mathrm{HR} \mathrm{0.78,} \mathrm{Cl} 0.63-0.97)$ receive Gpllb-IIla inhibitor therapy (O'donoghue et al., 2009)

Prasugrel resulted in greater platelet inhibition than clopidogrel in patients admitted with ACS both at 1-2 $\mathrm{h}$ and at 30 days (Michelson et al., 2009)

Prasugrel reduced incidence of primary endpoint at 30 days (HR $0.68, \mathrm{Cl} 0.54-0.87$ ) and 15 months (HR 0.79, Cl 0.65-0.97) in patients with STEMI; increased major post-CABG bleeding (HR 6.53, Cl 1.78-23.94; Montalescot et al., 2009)

SWAP trial

Phase II trial in patients after ACS on clopidogrel 75 daily and then randomized to continued clopidogrel, prasugrel $10 \mathrm{mg}$ daily, or prasugrel $60 \mathrm{mg}$ once then $10 \mathrm{mg}$ daily

Compared to maintenance clopidogrel, prasugrel therapy was associated with greater platelet inhibition as early as $2 \mathrm{~h}(60 \mathrm{mg}$ load then $10 \mathrm{mg}$ daily) and 6 days (10 mg daily) that persisted through 14 days (Angiolillo et al., 2010)

\section{TICAGRELOR}

\section{PLATO sub-studies}

Ticagrelor reduced primary endpoint ( $\mathrm{HR} 0.84, \mathrm{Cl} 0.75-0.94)$, no difference in major bleeding ( $\mathrm{HR} \mathrm{0.99,} \mathrm{Cl} 0.89-1.10)$ in those undergoing invasive strategy (Cannon et al., 2010)

In STEMI and planned reperfusion, ticagrelor reduced the incidence of primary endpoint ( $\mathrm{HR} 0.87, \mathrm{Cl} 0.75-1.01)$, and all cause mortality ( $\mathrm{HR} 0.82$, $\mathrm{Cl}$ 0.67-1.0), with no difference in major bleeding (Steg et al., 2010a)

In those with CKD ticagrelor reduced the incidence of primary endpoint ( $\mathrm{HR} 0.77, \mathrm{Cl} 0.65-0.90)$, and all cause mortality ( $\mathrm{HR} 0.72$, $\mathrm{Cl} 0.58-0.89$; James

et al., 2010)

\section{BIVALRUDIN}

HORIZONS-AMI

Acute stent thrombosis more frequent in patients randomized to bivalirudin (HR 4.43, Cl 1.52-12.92; Dangas et al., 2011)

Bivalirudin provided comparable reductions in primary endpoints irrespective of the necessity for transfer to PCl-able facility (Wohrle et al., 2010)

In high risk patients bivalirudin use reduced 1 year mortality (8.4 vs. $15.9 \%, p=0.014$ ) and reinfarction (3.6 vs. 7.9\%, $p=0.042$; Parodi et al., 2010)

Bivalirudin provided comparable reductions in net adverse clinical events in those receiving $300 \mathrm{mg}(12.3 \mathrm{vs} .15 .2 \%, p=0.15)$ and the $600 \mathrm{mg}(7.3 \mathrm{vs}$. $10.4 \%, p=0.01$ ) clopidogrel prior to $\mathrm{PCl}$ (Dangas et al., 2009)

Bivalirudin monotherapy reduced net adverse cardiac events ( $\mathrm{HR} 0.83, \mathrm{Cl} 0.71-0.97, p=0.02)$, and all cause mortality $(\mathrm{HR} 0.71, \mathrm{Cl} 0.51-0.98)$ at 12 months (Mehran et al., 2009a)

ACUITY sub-studies

Patients ( $n=14,000)$ with UA/NSTEMI randomized to heparin + Gpllb-IIla inhibitor, bivalirudin + Gpllb-IIla inhibitor, or bivalirudin alone. Primary endpoints: (1) death, NFMI, unplanned revascularization, (2) major bleeding, (3) ischemia and major bleeding

In those with CKD, bivalirudin reduced major bleeding (RR 0.64, $\mathrm{Cl} 45-0.89, p=0.008$ ) with comparable composite ischemia effect (RR 1.18, $\mathrm{Cl} 0.88-1.57$, $p=0.27$; Mehran et al., 2009b)

Bivalirudin was associated with reduced access-related major bleeding in patients that underwent femoral $(3.0$ vs. $5.8 \%, p<0.0001)$, but not radial access (4.2 vs. $2.2 \%, p=0.19 ;$ Hamon et al., 2009)

Among the elderly (>75 years old) bivalirudin resulted in comparable composite ischemia (11.7 vs. 9.6\%, NS), with fewer major bleeds $(5.8$ vs. $10.1 \%$, $p<0.05$, NNT 16; Lopes et al., 2009)

Bivalirudin was associated with similar rates of early ( $<30$ day) stent thrombosis (1.4 vs. $1.1 \%, p=0.37$; Aoki et al., 2009)

Bivalirudin was associated with less acquired thrombocytopenia (HR 0.75, Cl 0.61-0.93; Caixeta et al., 2011)

No relationship between the time to anti-thrombin initiation and ischemic outcomes in patients admitted with ACS. Thirty-day bleeding risk increased as time to anti-thrombin initiation increased (OR 1.44, Cl 1.15-1.80; Diercks et al., 2011)

Among patients undergoing $\mathrm{PCl}$ to vein grafts, there was a comparable incidence of major cardiac events and major bleeding with bivalirudin monotherapy (Kumar et al., 2010)

Among patients referred for medical therapy after angiography (32.4\%), bivalirudin resulted in less major bleeding (4.4 vs. $2.5 \%, p=0.005)$ with no difference in composite ischemia endpoint at 30 days (HR 0.87, Cl 0.55-1.37) or 1 year (HR 1.01, Cl 0.76-1.34; Goto et al., 2010a)

(Continued) 


\section{Table 4 | Continued}

\section{CLOPIDOGREL}

Retrospective registry study of retroperitoneal hemorrhage after PCl in Michigan between 2002 and 2007

Bivalirudin use was associated with significantly fewer retroperitoneal hemorrhages (OR 0.51, Cl 0.34-0.76, $p<0.001$; Trimarchi et al., 2010)

ACTION registry sub-study

Retrospective study of anti-coagulant strategy from January to December 2007 in patients with NSTEMI undergoing PCl $(n=11,085)$

Compared to reference heparin + Gpllb-IIla (64\%), bivalirudin alone (10.5\%) was associated with less major bleeding (OR $0.48, \mathrm{Cl} 0.39-0.60)$ and lower

in-hospital mortality (OR 0.39, Cl 0.21-0.71; Lopes et al., 2010)

\section{FONDAPARINUX}

OASIS-6 sub-study

Patients $(n=12,092)$ with STEMI were randomized to fondaparinux $(2.5 \mathrm{mg}$ daily) or UFH. Primary endpoint was death, MI, or refractory ischemia at 30 days

There were comparable reductions in the incidence composite death or $\mathrm{MI}$, as well as the incidence of major bleeding across age tertiles $\mathrm{Nan}$ Rees Vellinga et al., 2010)

\section{FUTURE/OASIS-8}

Standard (85 U/kg UFH bolus and ACT 300-350 or $60 \mathrm{U} / \mathrm{kg}$ and ACT 250-300 if Gpllb-llla) or low-dose (50 U/kg UFH bolus without ACT adjustment) heparin regimen during $\mathrm{PCl}$ in patients with NSTEMI that received initial fondaparinux

No difference between UFH regimens on composite major and minor bleeds (OR 0.80, $\mathrm{Cl} 0.54-1.12, p=0.27$ ) but a trend toward increased composite death, MI, TVR (OR 1.58, Cl 0.98-2.53, $p=0.06$; Steg et al., 2010b)

French registry of anti-coagulant use in the setting of ACS between January and December 2007

Adjusted 30 day mortality rates were higher in patients treated with UFH compared to fondaparinux as the initial (HR 3.1, Cl 1.3-7.4), and final anti-coagulant (HR 3.1, Cl 1.3-7.3; Schiele et al., 2010)

OASIS-5

Fondaparinux reduced major bleeding in patients receiving discretionary Gpllb-IIla inhibition (HR 0.60, $\mathrm{Cl} 0.46-0.78$ ) or pre-procedural thienopyridines (HR 0.62, Cl 0.52-0.73; Jolly et al., 2009)

Fondaparinux was associated with a cost savings of \$547 (CI \$207-\$924) per patient compared to enoxaparin therapy at 6 months (Sculpher et al., 2009) Fondaparinux was associated with a similar incidence primary endpoint (NS at all strata), and significantly lower risk of major bleeding with in patients with low (HR 0.55, $\mathrm{Cl}$ 0.39-0.77), medium (HR 0.53, Cl 0.40-0.70), and high (HR 0.50, Cl 0.38-0.64) risk of bleeding (Joyner et al., 2009)

\section{RIVAROXABAN}

ATLAS ACS TIMI 46

Patients with stabilized ACS $(n=3,491)$ randomized to rivaroxaban or placebo and treated for 6 months. Primary safety endpoint: clinically significant bleeding; Primary efficacy endpoint: death, NFMI, stroke, or recurrent ischemia

At $5 \mathrm{mg}$ twice daily, rivaroxaban was associated with increased bleeding (HR 1.71, $\mathrm{Cl}$ 0.76-3.85), and a non-significant reduction in primary efficacy endpoint (HR 0.60, Cl 0.29-1.25; Mega et al., 2009a)

\section{APIXABAN}

\section{APPRAISE}

Patients with stabilized ACS $(n=1,715)$ randomized to one of four doses of apixaban or placebo. Primary outcome was major or clinically relevant bleeding. Secondary outcome was CV death, MI, severe recurrent ischemia, or ischemic stroke

At the lowest dose studied, apixaban (2.5 mg twice daily) was associated with non-significant increases in bleeding ( $\mathrm{HR} 1.8, \mathrm{Cl} 0.91-2.48, p=0.09)$, and non-significant decreases in composite CV death, MI, recurrent ischemia, and stroke (HR 0.73, Cl 0.44-1.2, $p=0.21$; Alexander et al., 2009)

\section{OTAMIXABAN}

\section{SEPIA-ACS TIMI 42}

Patients with NSTEMI $(n=3,241)$ were randomized to one of five otamixaban doses or UFH plus eptifibatide. Primary efficacy endpoint: death, MI, urgent revascularization, or bailout Gpllb-IIla inhibitor use. Primary safety endpoint: CABG unrelated bleeding

Otamixaban at an intermediate dose $(0.105 \mathrm{mg} / \mathrm{kg} / \mathrm{h})$ was associated with reduced incidence of primary efficacy endpoint $(\mathrm{R} 0.61, \mathrm{Cl} 0.36-1.02)$, with a non-significant increase in bleeding (3.1 vs. 2.7\%; Sabatine et al., 2009)

planned PCI will be provided bivalirudin or UFH by emergency medical personnel.

Dabigatran is a synthetic, competitive, and reversible direct thrombin inhibitor with good oral bioavailability (Table 3; Figure 3). Recently approved for the prevention of stroke in patients with atrial fibrillation (Connolly et al., 2009), dabigatran is undergoing evaluation in ACS. In a phase II dose finding study, patients with ACS and at high risk for additional events were randomized to dabigatran twice daily or placebo a median of 7 days after the event and treated for 6 months. Preliminary findings demonstrated no difference in rate of composite cardiovascular death, non-fatal myocardial infarction, or stroke $(3.8 \%$ on placebo, $4.6 \% 50 \mathrm{mg}, 3.5 \% 150 \mathrm{mg})$ or the risk of bleeding $(0.54 \%$ on placebo, $0.81 \% 50 \mathrm{mg}, 1.73 \% 150 \mathrm{mg}$ ), although there was a 
trend toward increased minor bleeding at every dose (Oldgren et al., 2009).

\section{CONCLUSION}

Platelet aggregation and thrombus formation comprise the intermediary events between plaque instability and MI, and pharmacological inhibition of these events has led to substantial reductions in ischemic complications and mortality. Newer agents are characterized by more predictable pharmacokinetics, reduced

\section{REFERENCES}

Alexander, J. H., Becker, R. C., Bhatt, D. L., Cools, F., Crea, F., Dellborg, M., Fox, K. A., Goodman, S. G., Harrington, R. A., Huber, K., Husted, S., Lewis, B. S., LopezSendon, J., Mohan, P., Montalescot, G., Ruda, M., Ruzyllo, W., Verheugt, F., and Wallentin, L. (2009). Apixaban, an oral, direct, selective factor Xa inhibitor, in combination with antiplatelet therapy after acute coronary syndrome: results of the Apixaban for Prevention of Acute Ischemic and Safety Events (APPRAISE) trial. Circulation 119, 2877-2885.

Alexander, J. H., Lopes, R. D., James, S., Kilaru, R., He, Y., Mohan, P., Bhatt, D. L., Goodman, S., Verheugt, F. W., Flather, M., Huber, K., Liaw, D., Husted, S. E., Lopez-Sendon, J., De Caterina, R., Jansky, P., Darius, H., Vinereanu, D., Cornel, J. H., Cools, F., Atar, D., Leiva-Pons, J. L., Keltai, M., Ogawa, H., Pais, P., Parkhomenko, A., Ruzyllo, W., Diaz, R., White, H., Ruda, M., Geraldes, M., Lawrence, J., Harrington, R. A., and Wallentin, L. (2011). Apixaban with antiplatelet therapy after acute coronary syndrome. N. Engl. J. Med. 365, 699-708.

Angiolillo, D. J., Saucedo, J. F., Deraad, R., Frelinger, A. L., Gurbel, P. A., Costigan, T. M., Jakubowski, J. A., Ojeh, C. K., and Effron, M. B. (2010). Increased platelet inhibition after switching from maintenance clopidogrel to prasugrel in patients with acute coronary syndromes: results of the SWAP (Switching Anti Platelet) study. J. Am. Coll. Cardiol. 56, 1017-1023.

Angiolillo, D. J., Shoemaker, S. B., Desai, B., Yuan, H., Charlton, R. K., Bernardo, E., Zenni, M. M., Guzman, L. A., Bass, T. A., and Costa, M. A. (2007). Randomized comparison of a high clopidogrel maintenance dose in patients with diabetes mellitus and coronary artery disease: results of the Optimizing Antiplatelet Therapy In Diabetes Mellitus (OPTIMUS) study. Circulation 115, 708-716.
Antiplatelet Trialists' Collaboration. (1994). Collaborative overview of randomised trials of antiplatelet therapy -I: prevention of death, myocardial infarction, and stroke by prolonged antiplatelet therapy in various categories of patients. Antiplatelet Trialists' Collaboration. BMJ 308, 81-106.

Antithrombotic Trialists' Collaboration. (2002). Collaborative meta-analysis of randomised trials of antiplatelet therapy for prevention of death, myocardial infarction, and stroke in high risk patients. BMJ 324, 71-86.

Antman, E. M., Mccabe, C. H., Gurfinkel, E. P., Turpie, A. G., Bernink, P. J., Salein, D., Bayes De Luna, A., Fox, K., Lablanche, J. M., Radley, D., Premmereur, J., and Braunwald, E. (1999). Enoxaparin prevents death and cardiac ischemic events in unstable angina/non-Qwave myocardial infarction. Results of the thrombolysis in myocardial infarction (TIMI) 11B trial. Circulation 100, 1593-1601.

Antman, E. M., Morrow, D. A., Mccabe, C. H., Murphy, S. A., Ruda, M., Sadowski, Z., Budaj, A., Lopez-Sendon, J. L., Guneri, S., Jiang, F., White, H. D., Fox, K. A., and Braunwald, E. (2006). Enoxaparin versus unfractionated heparin with fibrinolysis for ST-elevation myocardial infarction. N. Engl. J. Med. 354, 1477-1488.

Antman, E. M., Wiviott, S. D., Murphy, S. A., Voitk, J., Hasin, Y., Widimsky, P., Chandna, H., Macias, W., Mccabe, C. H., and Braunwald, E. (2008). Early and late benefits of prasugrel in patients with acute coronary syndromes undergoing percutaneous coronary intervention: a TRITON-TIMI 38 (trial to assess improvement in therapeutic outcomes by optimizing platelet inhibition with prasugrel-thrombolysis in myocardial infarction) analysis. $J$. Am. Coll. Cardiol. 51, 2028-2033.

Aoki, J., Lansky, A. J., Mehran, R., Moses, J., Bertrand, M. E., Mclaurin, B. T., Cox, D. A., Lincoff, A. M., Ohman, E. M., White, H. D., Parise, H., Leon, M. B., and Stone, G. W. (2009). Early

inter-individual response variability, and activity at the site of coronary occlusion. Recently approved agents (bivalirudin, fondaparinux, prasugrel, ticagrelor) have improved outcomes in clinical trials by more effectively balancing the anti-ischemic benefits and bleeding risks during ACS. Identifying the timing and setting of anti-platelet and anti-coagulant initiation, and the subgroups in which one agent provides a comparably favorable risk-benefit profile remains an area of active investigation (Table 4).

stent thrombosis in patients with acute coronary syndromes treated with drug-eluting and bare metal stents: the Acute Catheterization and Urgent Intervention Triage Strategy trial. Circulation 119, 687-698.

Becker, R. C., Moliterno, D. J., Jennings, L. K., Pieper, K. S., Pei, J., Niederman, A., Ziada, K. M., Berman, G., Strony, J., Joseph, D., Mahaffey, K. W., Van De Werf, F., Veltri, E., and Harrington, R. A. (2009). Safety and tolerability of SCH 530348 in patients undergoing non-urgent percutaneous coronary intervention: a randomised, doubleblind, placebo-controlled phase II study. Lancet 373, 919-928.

Bittl, J. A., Chaitman, B. R., Feit, F., Kimball, W., and Topol, E. J. (2001). Bivalirudin versus heparin during coronary angioplasty for unstable or postinfarction angina: final report reanalysis of the Bivalirudin Angioplasty study. Am. Heart J. 142, 952-959.

Caixeta, A., Dangas, G. D., Mehran, R., Feit, F., Nikolsky, E., Lansky, A. J., Aoki, J., Moses, J. W., Steinhubl, S. R., White, H. D., Ohman, E. M., Manoukian, S. V., Fahy, M., and Stone, G. W. (2011). Incidence and clinical consequences of acquired thrombocytopenia after antithrombotic therapies in patients with acute coronary syndromes: results from the Acute Catheterization and Urgent Intervention Triage Strategy (ACUITY) trial. Am. Heart J. 161, 298-306.

Cannon, C. P., Harrington, R. A., James, S., Ardissino, D., Becker, R. C., Emanuelsson, H., Husted, S., Katus, H., Keltai, M., Khurmi, N. S., Kontny, F., Lewis, B. S., Steg, P. G., Storey, R. F., Wojdyla, D., and Wallentin, L. (2010). Comparison of ticagrelor with clopidogrel in patients with a planned invasive strategy for acute coronary syndromes (PLATO): a randomised double-blind study. Lancet 375, 283-293.

CAPRIE Steering Committee. (1996). A randomised, blinded, trial of clopidogrel versus aspirin in patients at risk of ischaemic events (CAPRIE). CAPRIE Steering Committee. Lancet 348, 1329-1339.

Chackalamannil, S., and Xia, Y. (2006). Thrombin receptor (PAR-1) antagonists as novel antithrombotic agents. Expert Opin. Ther. Pat. 16, 493-505.

Chin, C. T., Roe, M. T., Fox, K. A., Prabhakaran, D., Marshall, D. A., Petitjean, H., Lokhnygina, Y., Brown, E., Armstrong, P. W., White, H. D., and Ohman, E. M. (2010). Study design and rationale of a comparison of prasugrel and clopidogrel in medically managed patients with unstable angina/non-ST-segment elevation myocardial infarction: the targeted platelet inhibition to clarify the optimal strategy to medically manage acute coronary syndromes (TRILOGY ACS) trial. Am. Heart J. $160,16-22$

Cohen, M., Bhatt, D. L., Alexander, J. H., Montalescot, G., Bode, C., Henry, T., Tamby, J. F., Saaiman, J., Simek, S., and De Swart, J. (2007). Randomized, double-blind, dose-ranging study of otamixaban, a novel, parenteral, short-acting direct factor $\mathrm{Xa}$ inhibitor, in percutaneous coronary intervention: the SEPIA-PCI trial. Circulation 115, 2642-2651.

Cohen, M., Mahaffey, K. W., Pieper, K., Pollack, C. V. Jr., Antman, E. M., Hoekstra, J., Goodman, S. G., Langer, A., Col, J. J., White, H. D., Califf, R. M., and Ferguson, J. J. (2006) A subgroup analysis of the impact of prerandomization antithrombin therapy on outcomes in the SYNERGY trial: enoxaparin versus unfractionated heparin in non-STsegment elevation acute coronary syndromes. J. Am. Coll. Cardiol. 48, 1346-1354.

Connolly, S. J., Ezekowitz, M. D., Yusuf, S., Eikelboom, J., Oldgren, J., Parekh, A., Pogue, J., Reilly, P. A., Themeles, E., Varrone, J., Wang, S., Alings, M., Xavier, D., Zhu, J., Diaz, R., Lewis, B. S., Darius, H., Diener, H. C., Joyner, C. D., and Wallentin, L. (2009). Dabigatran versus warfarin in patients with atrial fibrillation. $N$. Engl. J. Med. 361, 1139-1151. 
Coussement, P. K., Bassand, J. P., Convens, C., Vrolix, M., Boland, J., Grollier, G., Michels, R., Vahanian, A., Vanderheyden, M., Rupprecht, H. J., and Van De Werf, F. (2001). A synthetic factor-Xa inhibitor (ORG31540/SR9017A) as an adjunct to fibrinolysis in acute myocardial infarction. The PENTALYSE study. Eur. Heart J. 22, 1716-1724.

Dangas, G., Mehran, R., Guagliumi, G., Caixeta, A., Witzenbichler, B., Aoki, J., Peruga, J. Z., Brodie, B. R., Dudek, D., Kornowski, R., Rabbani, L. E., Parise, H., and Stone, G. W. (2009). Role of clopidogrel loading dose in patients with ST-segment elevation myocardial infarction undergoing primary angioplasty: results from the HORIZONS-AMI (harmonizing outcomes with revascularization and stents in acute myocardial infarction) trial. J. Am. Coll. Cardiol. 54, 1438-1446.

Dangas, G. D., Mehran, R., Nikolsky, E., Claessen, B. E., Lansky, A. J., Brodie, B. R., Witzenbichler, B., Guagliumi, G., Peruga, J. Z., Dudek, D., Mockel, M., Caixeta, A., Parise, H., White, H., and Stone, G. W. (2011). Effect of switching antithrombin agents for primary angioplasty in acute myocardial infarction the HORIZONS-SWITCH analysis. J. Am. Coll. Cardiol. 57, 2309-2316.

Diercks, D. B., Pollack, C. V. Jr., Hollander, J. E., Blomkalns, A. L., Emerman, C. L., Rokos, I. C., Larson, D. M., Hoekstra, J. W., Mehran, R., and Stone, G. W. (2011). The time dependence of antithrombin initiation in patients with non-STsegment elevation acute coronary syndromes: subgroup analysis from the ACUITY trial. Ann. Emerg. Med. 57, 204-212.

Eikelboom, J. W., Hirsh, J., Weitz, J. I., Johnston, M., Yi, Q., and Yusuf, S. (2002). Aspirin-resistant thromboxane biosynthesis and the risk of myocardial infarction, stroke, or cardiovascular death in patients at high risk for cardiovascular events. Circulation 105, 1650-1655.

Ferguson, J. J., Califf, R. M., Antman, E. M., Cohen, M., Grines, C. L., Goodman, S., Kereiakes, D. J., Langer, A., Mahaffey, K. W., Nessel, C. C., Armstrong, P. W., Avezum, A., Aylward, P., Becker, R. C., Biasucci, L., Borzak, S., Col, J., Frey, M. J., Fry, E., Gulba, D. C., Guneri, S., Gurfinkel, E., Harrington, R., Hochman, J. S., Kleiman, N. S., Leon, M. B., Lopez-Sendon, J. L., Pepine, C. J., Ruzyllo, W., Steinhubl, S. R.,
Teirstein, P. S., Toro-Figueroa, L., and White, H. (2004). Enoxaparin vs. unfractionated heparin in highrisk patients with non-ST-segment elevation acute coronary syndromes managed with an intended early invasive strategy: primary results of the SYNERGY randomized trial. JAMA 292, 45-54.

FRAX. I. S. Study Group. (1999). Comparison of two treatment durations ( 6 days and 14 days) of a low molecular weight heparin with a 6-day treatment of unfractionated heparin in the initial management of unstable angina or non-Q wave myocardial infarction: FRAX. I. S. (FRAxiparine in Ischaemic Syndrome). Eur. Heart J. 20, 1553-1562.

FRISC Study Group. (1996). Lowmolecular-weight heparin during instability in coronary artery disease, fragmin during instability in coronary artery disease (FRISC) study group. Lancet 347, 561-568.

Gasparyan, A. Y., Watson, T., and Lip, G. Y. (2008). The role of aspirin in cardiovascular prevention: implications of aspirin resistance. J. Am. Coll. Cardiol. 51, 1829-1843.

Gladding, P., Webster, M., Zeng, I., Farrell, H., Stewart, J., Ruygrok, P., Ormiston, J., El-Jack, S., Armstrong, G., Kay, P., Scott, D., Gunes, A., and Dahl, M. L. (2008). The pharmacogenetics and pharmacodynamics of clopidogrel response: an analysis from the PRINC (Plavix Response in Coronary Intervention) trial. JACC Cardiovasc. Interv. 1, 620-627.

Goodman, S. G., Cohen, M., Bigonzi, F., Gurfinkel, E. P., Radley, D. R., Le Iouer, V., Fromell, G. J., Demers, C., Turpie, A. G., Califf, R. M., Fox, K. A., and Langer, A. (2000). Randomized trial of low molecular weight heparin (enoxaparin) versus unfractionated heparin for unstable coronary artery disease: one-year results of the ESSENCE study. Efficacy and Safety of Subcutaneous Enoxaparin in Non-Q Wave Coronary Events. J. Am. Coll. Cardiol. 36, 693-698.

Goto, K., Lansky, A. J., Fahy, M., Cristea, E., Feit, F., Ohman, E. M., White, H. D., Alexander, K. P., Bertrand, M. E., Desmet, W., Hamon, M., Mehran, R., and Stone, G. W. (2010a). Predictors of outcomes in medically treated patients with acute coronary syndromes after angiographic triage: an Acute Catheterization And Urgent Intervention Triage Strategy (ACUITY) substudy. Circulation 121, 853-862.

Goto, S., Ogawa, H., Takeuchi, M., Flather, M. D., and Bhatt,
D. L. (2010b). Double-blind, placebo-controlled phase II studies of the protease-activated receptor 1 antagonist E5555 (atopaxar) in Japanese patients with acute coronary syndrome or high-risk coronary artery disease. Eur. Heart J. 31, 2601-2613.

Gum, P. A., Kottke-Marchant, K., Poggio, E. D., Gurm, H., Welsh, P. A., Brooks, L., Sapp, S. K., and Topol, E. J. (2001). Profile and prevalence of aspirin resistance in patients with cardiovascular disease. Am. J. Cardiol. 88, 230-235.

Gum, P. A., Kottke-Marchant, K., Welsh, P. A., White, J., and Topol, E. J. (2003). A prospective, blinded determination of the natural history of aspirin resistance among stable patients with cardiovascular disease. J. Am. Coll. Cardiol. 41, 961-965.

Hamon, M., Rasmussen, L. H., Manoukian, S. V., Cequier, A., Lincoff, M. A., Rupprecht, H. J., Gersh, B. J., Mann, T., Bertrand, M. E., Mehran, R., and Stone, G. W. (2009). Choice of arterial access site and outcomes in patients with acute coronary syndromes managed with an early invasive strategy: the ACUITY trial. EuroIntervention 5, 115-120.

Hennekens, C. H., Schror, K., Weisman, S., and Fitzgerald, G. A. (2004). Terms and conditions: semantic complexity and aspirin resistance. Circulation 110, 1706-1708.

Hochholzer, W., Trenk, D., Bestehorn, H. P., Fischer, B., Valina, C. M., Ferenc, M., Gick, M., Caputo, A., Buttner, H. J., and Neumann, F. J. (2006). Impact of the degree of peri-interventional platelet inhibition after loading with clopidogrel on early clinical outcome of elective coronary stent placement. J. Am. Coll. Cardiol. 48, 1742-1750.

Husted, S., Emanuelsson, H., Heptinstall, S., Sandset, P. M., Wickens, M., and Peters, G. (2006). Pharmacodynamics, pharmacokinetics, and safety of the oral reversible P2Y12 antagonist AZD6140 with aspirin in patients with atherosclerosis: a double-blind comparison to clopidogrel with aspirin. Eur. Heart J. 27, 1038-1047.

ISIS Collaborative Group. (1988). Randomized trial of intravenous streptokinase, oral aspirin, both, or neither among 17,187 cases of suspected acute myocardial infarction: ISIS-2.ISIS-2 (Second International Study of Infarct Survival) collaborative group. J. Am. Coll. Cardiol. 12, 3A-13A.
James, S., Budaj, A., Aylward, P., Buck, K. K., Cannon, C. P., Cornel, J. H., Harrington, R. A., Horrow, J., Katus, H., Keltai, M., Lewis, B. S., Parikh, K., Storey, R. F., Szummer, K., Wojdyla, D., and Wallentin, L. (2010). Ticagrelor versus clopidogrel in acute coronary syndromes in relation to renal function: results from the platelet inhibition and patient outcomes (PLATO) trial. Circulation 122, 1056-1067.

Jolly, S. S., Faxon, D. P., Fox, K. A., Afzal, R., Boden, W. E., Widimsky, P., Steg, P. G., Valentin, V., Budaj, A., Granger, C. B., Joyner, C. D., Chrolavicius, S., Yusuf, S., and Mehta, S. R. (2009). Efficacy and safety of fondaparinux versus enoxaparin in patients with acute coronary syndromes treated with glycoprotein IIb/IIIa inhibitors or thienopyridines: results from the OASIS 5 (Fifth Organization to Assess Strategies in Ischemic Syndromes) trial. J. Am. Coll. Cardiol. 54, 468-476.

Joyner, C. D., Peters, R. J., Afzal, R., Chrolavicius, S., Mehta, S. R., Fox, K. A., Granger, C. B., Franzosi, M. G., Flather, M., Budaj, A., Bassand, J. P., and Yusuf, S. (2009). Fondaparinux compared to enoxaparin in patients with acute coronary syndromes without STsegment elevation: outcomes and treatment effect across different levels of risk. Am. Heart J. 157, 502-508.

Katsouras, C., Michalis, L. K., Papamichael, N., Adamides, K. Naka, K. K., Nikas, D., Goudevenos J. A., and Sideris, D. A. (2005). Enoxaparin versus tinzaparin in non-ST-segment elevation acute coronary syndromes: results of the enoxaparin versus tinzaparin (EVET) trial at 6 months. Am. Heart J. 150, 385-391.

Kim, K. A., Park, P. W., Hong, S. J., and Park, J. Y. (2008). The effect of CYP2C19 polymorphism on the pharmacokinetics and pharmacodynamics of clopidogrel: a possible mechanism for clopidogrel resistance. Clin. Pharmacol. Ther. 84, 236-242.

Klein, W., Buchwald, A., Hillis, S. E., Monrad, S., Sanz, G., Turpie, A. G., Van Der Meer, J., Olaisson, E., Undeland, S., and Ludwig, K. (1997). Comparison of low-molecular-weight heparin with unfractionated heparin acutely and with placebo for 6 weeks in the management of unstable coronary artery disease. Fragmin in unstable coronary artery disease study (FRIC). Circulation 96, 61-68. 
Kubica, A., Kozinski, M., Grzesk, G., Fabiszak, T., Navarese, E. P., and Goch, A. (2011). Genetic determinants of platelet response to clopidogrel. J. Thromb. Thrombolysis 32, 459-466.

Kumar, D., Dangas, G., Mehran, R., Kirtane, A., Bertrand, M., Ebrahimi, R., Guagliumi, G., Brar, S., Fahy, M., Heller, E., Moses, J., and Stone, G. (2010). Comparison of bivalirudin versus bivalirudin plus glycoprotein IIb/IIIa inhibitor versus heparin plus glycoprotein IIb/IIIa inhibitor in patients with acute coronary syndromes having percutaneous intervention for narrowed saphenous vein aorto-coronary grafts (the ACUITY trial investigators). Am. J. Cardiol. 106, 941-945.

Lewis, H. D. Jr., Davis, J. W., Archibald, D. G., Steinke, W. E., Smitherman, T. C., Doherty, J. E. III, Schnaper, H. W., Lewinter, M. M., Linares, E., Pouget, J. M., Sabharwal, S. C., Chesler, E., and Demots, H. (1983). Protective effects of aspirin against acute myocardial infarction and death in men with unstable angina. Results of a Veterans Administration Cooperative Study. N. Engl. J. Med. 309, 396-403.

Lincoff, A. M., Bittl, J. A., Harrington, R. A., Feit, F., Kleiman, N. S., Jackman, J. D., Sarembock, I. J., Cohen, D. J., Spriggs, D., Ebrahimi, R., Keren, G., Carr, J., Cohen, E. A., Betriu, A., Desmet, W., Kereiakes, D. J., Rutsch, W., Wilcox, R. G., De Feyter, P. J., Vahanian, A., and Topol, E. J. (2003). Bivalirudin and provisional glycoprotein IIb/IIIa blockade compared with heparin and planned glycoprotein IIb/IIIa blockade during percutaneous coronary intervention: REPLACE-2 randomized trial. JAMA 289, 853-863.

Lincoff, A. M., Kleiman, N. S., KottkeMarchant, K., Maierson, E. S., Maresh, K., Wolski, K. E., and Topol, E. J. (2002). Bivalirudin with planned or provisional abciximab versus low-dose heparin and abciximab during percutaneous coronary revascularization: results of the comparison of abciximab complications with hirulog for ischemic events trial (CACHET). Am. Heart J. 143, 847-853.

Lopes, R. D., Alexander, K. P., Manoukian, S. V., Bertrand, M. E., Feit, F., White, H. D., Pollack, C. V. Jr., Hoekstra, J., Gersh, B. J., Stone, G. W., and Ohman, E. M. (2009). Advanced age, antithrombotic strategy, and bleeding in non-ST-segment elevation acute coronary syndromes: results from the ACUITY (Acute Catheterization and Urgent Intervention Triage Strategy) trial. J. Am. Coll. Cardiol. 53, 1021-1030.

Lopes, R. D., Peterson, E. D., Chen, A. Y., Roe, M. T., Wang, T. Y., Ohman, E. M., Magid, D. J., Ho, P. M., Wiviott, S. D., Scirica, B. M., and Alexander, K. P. (2010). Antithrombotic strategy in non-ST-segment elevation myocardial infarction patients undergoing percutaneous coronary intervention: insights from the ACTION (acute coronary treatment and intervention outcomes network) registry. JACC Cardiovasc. Interv. 3, 669-677.

Mega, J. L., Braunwald, E., Mohanavelu, S., Burton, P., Poulter, R., Misselwitz, F., Hricak, V., Barnathan, E. S., Bordes, P., Witkowski, A., Markov, V., Oppenheimer, L., and Gibson, C. M. (2009a). Rivaroxaban versus placebo in patients with acute coronary syndromes (ATLAS ACSTIMI 46): a randomised, doubleblind, phase II trial. Lancet 374, 29-38.

Mega, J. L., Close, S. L., Wiviott, S. D., Shen, L., Hockett, R. D., Brandt, J. T., Walker, J. R., Antman, E. M., Macias, W. L., Braunwald, E., and Sabatine, M. S. (2009b). Cytochrome P450 genetic polymorphisms and the response to prasugrel: relationship to pharmacokinetic, pharmacodynamic, and clinical outcomes. Circulation 119, 2553-2560.

Mehran, R., Lansky, A. J., Witzenbichler, B., Guagliumi, G., Peruga, J. Z., Brodie, B. R., Dudek, D., Kornowski, R., Hartmann, F., Gersh, B. J., Pocock, S. J., Wong, S. C., Nikolsky, E., Gambone, L., Vandertie, L., Parise, H., Dangas, G. D., and Stone, G. W. (2009a). Bivalirudin in patients undergoing primary angioplasty for acute myocardial infarction (HORIZONS-AMI): 1-year results of a randomised controlled trial. Lancet 374, 1149-1159.

Mehran, R., Nikolsky, E., Lansky, A. J., Kirtane, A. J., Kim, Y. H., Feit, F., Manoukian, S., Moses, J. W., Ebrahimi, R., Ohman, E. M., White, H. D., Pocock, S. J., Dangas, G. D., and Stone, G. W. (2009b). Impact of chronic kidney disease on early (30-day) and late (1-year) outcomes of patients with acute coronary syndromes treated with alternative antithrombotic treatment strategies: an ACUITY (Acute Catheterization and Urgent Intervention Triage Strategy) substudy. JACC Cardiovasc. Interv. 2, 748-757.

Mehta, S. R., Yusuf, S., Peters, R. J., Bertrand, M. E., Lewis, B. S., Natarajan, M. K., Malmberg, K., Rupprecht,
H., Zhao, F., Chrolavicius, S., Copland, I., and Fox, K. A. (2001) Effects of pretreatment with clopidogrel and aspirin followed by longterm therapy in patients undergoing percutaneous coronary intervention: the PCI-CURE study. Lancet 358, 527-533.

Michalis, L. K., Katsouras, C. S., Papamichael, N., Adamides, K., Naka, K. K., Goudevenos, J., and Sideris, D. A. (2003). Enoxaparin versus tinzaparin in non-STsegment elevation acute coronary syndromes: the EVET trial. Am. Heart J. 146, 304-310.

Michelson, A. D., Frelinger, A. L. III, Braunwald, E., Downey, W. E., Angiolillo, D. J., Xenopoulos, N. P., Jakubowski, J. A., Li, Y., Murphy, S. A., Qin, J., Mccabe, C. H., Antman, E. M., and Wiviott, S. D. (2009). Pharmacodynamic assessment of platelet inhibition by prasugrel vs. clopidogrel in the TRITON-TIMI 38 trial. Eur. Heart J. 30, 1753-1763.

Montalescot, G., Wiviott, S. D., Braunwald, E., Murphy, S. A., Gibson, C. M., Mccabe, C. H., and Antman, E. M. (2009). Prasugrel compared with clopidogrel in patients undergoing percutaneous coronary intervention for ST-elevation myocardial infarction (TRITON-TIMI 38): doubleblind, randomised controlled trial. Lancet 373, 723-731.

Morrow, D. A., Scirica, B. M., Fox, K. A., Berman, G., Strony, J., Veltri, E., Bonaca, M. P., Fish, P., Mccabe, C. H., and Braunwald, E. (2009). Evaluation of a novel antiplatelet agent for secondary prevention in patients with a history of atherosclerotic disease: design and rationale for the thrombin-receptor antagonist in Secondary Prevention of Atherothrombotic Ischemic Events (TRA 2 degrees P)-TIMI 50 trial. Am. Heart J. 158, 335-341.

Moshfegh, K., Redondo, M., Julmy, F., Wuillemin, W. A., Gebauer, M. U., Haeberli, A., and Meyer, B. J. (2000). Antiplatelet effects of clopidogrel compared with aspirin after myocardial infarction: enhanced inhibitory effects of combination therapy. $J$. Am. Coll. Cardiol. 36, 699-705.

Murphy, S. A., Gibson, C. M., Morrow, D. A., Van De Werf, F., Menown, I. B., Goodman, S. G., Mahaffey, K. W., Cohen, M., Mccabe, C. H., Antman, E. M., and Braunwald, E. (2007). Efficacy and safety of the low-molecular weight heparin enoxaparin compared with unfractionated heparin across the acute coronary syndrome spectrum: a meta-analysis. Eur. Heart J. 28 , 2077-2086.
O'donoghue, M., Antman, E. M., Braunwald, E., Murphy, S. A., Steg, P. G. Finkelstein, A., Penny, W. F., Fridrich, V., Mccabe, C. H., Sabatine, M. S., and Wiviott, S. D. (2009). The efficacy and safety of prasugrel with and without a glycoprotein IIb/IIIa inhibitor in patients with acute coronary syndromes undergoing percutaneous intervention: a TRITONTIMI 38 (trial to assess improvement in therapeutic outcomes by optimizing platelet inhibition with prasugrel-thrombolysis in myocardial infarction 38) analysis. J. Am. Coll. Cardiol. 54, 678-685.

Oldgren, J., Budaj, A.,Granger, C. B., Harper, R., Khder, Y., van de Werf, F., and Wallentin, L. (2009). LB04: randomised dabigatran etexilate dose finding study in patients with acute coronary syndromes post index event with additional risk factors for cardiovascular complications also receiving aspirin and clopidogrel (RE-DEEM), AHA 52.

Parodi, G., Antoniucci, D., Nikolsky, E., Witzenbichler, B., Guagliumi, G., Peruga, J. Z., Stuckey, T., Dudek, D., Kornowski, R., Hartmann, F., Lansky, A. J., Mehran, R., and Stone, G. W. (2010). Impact of bivalirudin therapy in highrisk patients with acute myocardial infarction: 1-year results from the HORIZONS-AMI (Harmonizing Outcomes with Revascularization and Stents in Acute Myocardial Infarction) trial. JACC Cardiovasc. Interv. 3, 796-802.

Price, M. J., Berger, P. B., Teirstein, P. S., Tanguay, J. F., Angiolillo, D. J., Spriggs, D., Puri, S., Robbins, M., Garratt, K. N., Bertrand, O. F., Stillabower, M. E., Aragon, J. R., Kandzari, D. E., Stinis, C. T., Lee, M. S., Manoukian, S. V., Cannon, C. P., Schork, N. J., and Topol, E. J. (2011). Standard- vs. high-dose clopidogrel based on platelet function testing after percutaneous coronary intervention: the GRAVITAS randomized trial. JAMA 305, 1097-1105.

Pride, Y. B., Wiviott, S. D., Buros, J. L., Zorkun, C., Tariq, M. U., Antman, E. M., Braunwald, E., and Gibson, C. M. (2009). Effect of prasugrel versus clopidogrel on outcomes among patients with acute coronary syndrome undergoing percutaneous coronary intervention without stent implantation: a trial to assess improvement in therapeutic outcomes by optimizing platelet inhibition with prasugrel (triton)-thrombolysis in myocardial infarction (TIMI) 38 substudy. Am. Heart J. 158, e21-e26. 
Robson, R. (2000). The use of bivalirudin in patients with renal impairment. J. Invasive Cardiol. 12(Suppl. F), 33F-36F

Rothberg, M. B., Celestin, C., Fiore, L. D., Lawler, E., and Cook, J. R. (2005). Warfarin plus aspirin after myocardial infarction or the acute coronary syndrome: metaanalysis with estimates of risk and benefit. Ann. Intern. Med. 143, 241-250.

Sabatine, M. S., Antman, E. M., Widimsky, P., Ebrahim, I. O., Kiss, R. G., Saaiman, A., Polasek, R., Contant, C. F., Mccabe, C. H., and Braunwald, E. (2009). Otamixaban for the treatment of patients with nonST-elevation acute coronary syndromes (SEPIA-ACS1 TIMI 42): a randomised, double-blind, activecontrolled, phase 2 trial. Lancet 374 , 787-795.

Schiele, F., Meneveau, N., Seronde, M. F., Descotes-Genon, V., Dutheil, J., Chopard, R., Ecarnot, F., and Bassand, J. P. (2010). Routine use of fondaparinux in acute coronary syndromes: a 2-year multicenter experience. Am. Heart J. 159, 190-198.

Sculpher, M. J., Lozano-Ortega, G., Sambrook, J., Palmer, S., Ormanidhi, O., Bakhai, A., Flather, M., Steg, P. G., Mehta, S. R., and Weintraub, W. (2009). Fondaparinux versus enoxaparin in non-ST-elevation acute coronary syndromes: shortterm cost and long-term costeffectiveness using data from the Fifth Organization to Assess Strategies in Acute Ischemic Syndromes Investigators (OASIS-5) trial. Am. Heart J. 157, 845-852.

Sibbing, D., Busch, G., Braun, S., Jawansky, S., Schomig, A., Kastrati, A., Ott, I., and Von Beckerath, N. (2008). Impact of bivalirudin or unfractionated heparin on platelet aggregation in patients pretreated with $600 \mathrm{mg}$ clopidogrel undergoing elective percutaneous coronary intervention. Eur. Heart J. 29, 1504-1509.

Simoons, M. L., Bobbink, I. W., Boland, J., Gardien, M., Klootwijk, P., Lensing, A. W., Ruzyllo, W., Umans, V. A., Vahanian, A., Van De Werf, F., and Zeymer, U. (2004). A dose-finding study of fondaparinux in patients with nonST-segment elevation acute coronary syndromes: the pentasaccharide in unstable angina (PENTUA) study. J. Am. Coll. Cardiol. 43, 2183-2190.

Steg, P. G., James, S., Harrington, R. A., Ardissino, D., Becker, R. C.,
Cannon, C. P., Emanuelsson, H., Finkelstein, A., Husted, S., Katus, H., Kilhamn, J., Olofsson, S., Storey, R. F., Weaver, W. D., and Wallentin, L. (2010a). Ticagrelor versus clopidogrel in patients with STelevation acute coronary syndromes intended for reperfusion with primary percutaneous coronary intervention: a platelet inhibition and patient outcomes (PLATO) trial subgroup analysis. Circulation 122, 2131-2141.

Steg, P. G., Jolly, S. S., Mehta, S. R., Afzal, R., Xavier, D., Rupprecht, H. J., Lopez-Sendon, J. L., Budaj, A., Diaz, R., Avezum, A., Widimsky, P., Rao, S. V., Chrolavicius, S., Meeks, B., Joyner, C., Pogue, J., and Yusuf, S. (2010b). Low-dose vs. standard-dose unfractionated heparin for percutaneous coronary intervention in acute coronary syndromes treated with fondaparinux: the FUTURA/OASIS8 randomized trial. JAMA 304, 1339-1349.

Stone, G. W., Mclaurin, B. T., Cox, D. A., Bertrand, M. E., Lincoff, A. M., Moses, J. W., White, H. D., Pocock, S. J., Ware, J. H., Feit, F., Colombo, A., Aylward, P. E., Cequier, A. R., Darius, H., Desmet, W., Ebrahimi, R., Hamon, M., Rasmussen, L. H., Rupprecht, H. J., Hoekstra, J., Mehran, R., and Ohman, E. M. (2006). Bivalirudin for patients with acute coronary syndromes. N. Engl. J. Med. 355, 2203-2216.

Storey, R. F., Husted, S., Harrington, R. A., Heptinstall, S., Wilcox, R. G., Peters, G., Wickens, M., Emanuelsson, H., Gurbel, P., Grande, P., and Cannon, C. P. (2007). Inhibition of platelet aggregation by AZD6140, a reversible oral P2Y12 receptor antagonist, compared with clopidogrel in patients with acute coronary syndromes. J. Am. Coll. Cardiol. 50, 1852-1856.

Sun, Y. P., Oh, S. F., Uddin, J., Yang, R., Gotlinger, K., Campbell, E., Colgan, S. P., Petasis, N. A., and Serhan, C. N. (2007). Resolvin D1 and its aspirintriggered 17R epimer. Stereochemical assignments, anti-inflammatory properties, and enzymatic inactivation. J. Biol. Chem. 282, 9323-9334.

Trimarchi, S., Smith, D. E., Share, D., Jani, S. M., O'donnell, M., Mcnamara, R., Riba, A., KlineRogers, E., Gurm, H. S., and Moscucci, M. (2010). Retroperitoneal hematoma after percutaneous coronary intervention: prevalence, risk factors, management, outcomes, and predictors of mortality: a report from the BMC2 (Blue Cross Blue
Shield of Michigan Cardiovascular Consortium) registry. JACC Cardiovasc. Interv. 3, 845-850.

Van De Werf, F. (2010). Thrombin receptor antagonists may become an important antiplatelet therapy for coronary artery disease. Eur. Heart J. 31, 2575-2576.

Van Rees Vellinga, T. E., Peters, R J., Yusuf, S., Afzal, R., Chrolavicius, S., O'donnell, M., Mehta, S. R., Pluta, W., Sacha, J., and Eikelboom, J. W. (2010). Efficacy and safety of fondaparinux in patients with ST-segment elevation myocardial infarction across the age spectrum. Results from the Organization for the Assessment of Strategies for Ischemic Syndromes 6 (OASIS-6) trial. Am. Heart J. 160, 1049-1055.

Virmani, R., Kolodgie, F. D., Burke, A. P., Farb, A., and Schwartz, S. M. (2000). Lessons from sudden coronary death: a comprehensive morphological classification scheme for atherosclerotic lesions. Arterioscler. Thromb. Vasc. Biol. 20, 1262-1275.

Wallentin, L., Becker, R. C., Budaj, A., Cannon, C. P., Emanuelsson, H., Held, C., Horrow, J., Husted, S., James, S., Katus, H., Mahaffey, K. W., Scirica, B. M., Skene, A., Steg, P. G., Storey, R. F., Harrington, R. A., Freij, A., and Thorsen, M. (2009). Ticagrelor versus clopidogrel in patients with acute coronary syndromes. N. Engl. J. Med. 361 , 1045-1057.

Wallentin, L., Goldstein, P., Armstrong, P. W., Granger, C. B., Adgey, A. A., Arntz, H. R., Bogaerts, K. Danays, T., Lindahl, B., Makijarvi, M., Verheugt, F., and Van De Werf, F. (2003). Efficacy and safety of tenecteplase in combination with the low-molecular-weight heparin enoxaparin or unfractionated heparin in the prehospital setting: the Assessment of the Safety and Efficacy of a New Thrombolytic Regimen (ASSENT)-3 PLUS randomized trial in acute myocardial infarction. Circulation 108, 135-142.

Wiviott, S. D., Trenk, D., Frelinger, A. L., O'donoghue, M., Neumann, F. J. Michelson, A. D., Angiolillo, D. J., Hod, H., Montalescot, G., Miller, D. L., Jakubowski, J. A., Cairns, R., Murphy, S. A., Mccabe, C. H., Antman, E. M., and Braunwald, E. (2007). Prasugrel compared with high loading- and maintenance-dose clopidogrel in patients with planned percutaneous coronary intervention: the prasugrel in comparison to clopidogrel for inhibition of platelet activation and aggregationthrombolysis in myocardial infarction 44 trial. Circulation 116, 2923-2932.

Wohrle, J., Desaga, M., Metzger, C., Huber, K., Suryapranata, H., Guetta, V., Guagliumi, G., Witzenbichler, B., Parise, H., Mehran, R., and Stone, G. W. (2010). Impact of transfer for primary percutaneous coronary intervention on survival and clinical outcomes (from the HORIZONSAMI Trial). Am. J. Cardiol. 106, 1218-1224.

Wright, R. S., Anderson, J. L., Adams, C. D., Bridges, C. R., Casey, D. E. Jr., Ettinger, S. M., Fesmire, F. M., Ganiats, T. G., Jneid, H., Lincoff, A M., Peterson, E. D., Philippides, G. J., Theroux, P., Wenger, N. K., Zidar, J. P., and Jacobs, A. K. (2011). 2011 ACCF/AHA Focused update of the guidelines for the management of patients with unstable angina/nonST-elevation myocardial infarction (updating the 2007 guideline): A report of the American College of Cardiology Foundation/American Heart Association task force on practice guidelines. Circulation 123, 2022-2060.

Xiao, Z., and Theroux, P. (1998). Platelet activation with unfractionated heparin at therapeutic concentrations and comparisons with a low-molecular-weight heparin and with a direct thrombin inhibitor. Circulation 97, 251-256.

Yeh, R. W., Sidney, S., Chandra, M., Sorel, M., Selby, J. V., and Go, A. S. (2010). Population trends in the incidence and outcomes of acute myocardial infarction. N. Engl. J. Med. 362, 2155-2165.

Yusuf, S., Mehta, S. R., Chrolavicius, S., Afzal, R., Pogue, J., Granger, C. B., Budaj, A., Peters, R. J., Bassand, J. P., Wallentin, L., Joyner, C., and Fox, K. A. (2006a). Comparison of fondaparinux and enoxaparin in acute coronary syndromes. N. Engl. J. Med. 354, 1464-1476.

Yusuf, S., Mehta, S. R., Chrolavicius, S., Afzal, R., Pogue, J., Granger, C. B., Budaj, A., Peters, R. J., Bassand, J. P., Wallentin, L., Joyner, C., and Fox, K. A. (2006b). Effects of fondaparinux on mortality and reinfarction in patients with acute ST-segment elevation myocardial infarction: the OASIS6 randomized trial. JAMA 295 $1519-1530$

Yusuf, S., Zhao, F., Mehta, S. R. Chrolavicius, S., Tognoni, G., and 
Fox, K. K. (2001). Effects of clopidogrel in addition to aspirin in patients with acute coronary syndromes without ST-segment elevation. N. Engl. J. Med. 345, 494-502.

Conflict of Interest Statement: The authors declare that the research was conducted in the absence of any commercial or financial relationships that could be construed as a potential conflict of interest.

Received: 01 September 2011; accepted: 25 September 2011; published online: 24 October 2011.
Citation: Lilly SM and Wilensky RL (2011) Emerging therapies for acute coronary syndromes. Front. Pharmacol. 2:61. doi: 10.3389/fphar.2011.00061

This article was submitted to Frontiers in Cardiovascular and Smooth Muscle Pharmacology, a specialty of Frontiers in Pharmacology.
Copyright (c) 2011 Lilly and Wilensky. This is an open-access article subject to a non-exclusive license between the authors and Frontiers Media SA, which permits use, distribution and reproduction in other forums, provided the original authors and source are credited and other Frontiers conditions are complied with. 